University of Nebraska - Lincoln

DigitalCommons@University of Nebraska - Lincoln

USGS Staff - Published Research

US Geological Survey

2002

\title{
Last Interglacial Climates
}

\author{
George J. Kukla \\ Lamont-Doherty Earth Observatory \\ Michael L. Bender \\ Princeton University \\ Jacques-Louis de Beaulieu \\ Faculte des Sciences et Techniques St. Jerome \\ Gerard Bond \\ Lamont-Doherty Earth Observatory \\ Wallace S. Broecker \\ Lamont-Doherty Earth Observatory \\ See next page for additional authors
}

Follow this and additional works at: https://digitalcommons.unl.edu/usgsstaffpub

Part of the Earth Sciences Commons

Kukla, George J.; Bender, Michael L.; de Beaulieu, Jacques-Louis; Bond, Gerard; Broecker, Wallace S.; Cleveringa, Piet; Gavin, Joyce E.; Herbert, Timothy D.; Imbrie, John; Jouzel, Jean; Keigwin, Lloyd D.; Knudsen, Karen-Luise; McManus, Jerry F.; Merkt, Josef; Muhs, Daniel R.; Muller, Helmut; Poore, Richard Z.; Porter, Stephen C.; Seret, Guy; Shackleton, Nicholas J.; Turner, Charles; Tzedakis, Polychronis C.; and Winograd, Isaac J., "Last Interglacial Climates" (2002). USGS Staff -- Published Research. 174.

https://digitalcommons.unl.edu/usgsstaffpub/174

This Article is brought to you for free and open access by the US Geological Survey at DigitalCommons@University of Nebraska - Lincoln. It has been accepted for inclusion in USGS Staff -- Published Research by an authorized administrator of DigitalCommons@University of Nebraska - Lincoln. 


\section{Authors}

George J. Kukla, Michael L. Bender, Jacques-Louis de Beaulieu, Gerard Bond, Wallace S. Broecker, Piet Cleveringa, Joyce E. Gavin, Timothy D. Herbert, John Imbrie, Jean Jouzel, Lloyd D. Keigwin, Karen-Luise Knudsen, Jerry F. McManus, Josef Merkt, Daniel R. Muhs, Helmut Muller, Richard Z. Poore, Stephen C.

Porter, Guy Seret, Nicholas J. Shackleton, Charles Turner, Polychronis C. Tzedakis, and Isaac J. Winograd 
Quaternary Research 58, 2-13 (2002)

doi:10.1006/qres.2001.2316

\title{
Last Interglacial Climates
}

\author{
George J. Kukla \\ Lamont-Doherty Earth Observatory, Palisades, New York 10964 \\ E-mail: kukla@ldeo.columbia.edu \\ Michael L. Bender \\ Department of Geosciences, Princeton University, Princeton, New Jersey, 08544 \\ Jacques-Louis de Beaulieu \\ Laboratoire de Botanique Historique et Palynologie, URA CNRS D1152, Faculte des Sciences et Techniques St. Jérôme, \\ Boîte 451, F-13397 Marseille Cedex 20, France \\ Gerard Bond and Wallace S. Broecker \\ Lamont-Doherty Earth Observatory, Palisades, New York 10964 \\ Piet Cleveringa \\ Netherlands Institute of Applied Geoscience TNO, National Geological Survey, P.O. Box 80015, 3508 TA Utrecht, The Netherlands \\ Joyce E. Gavin \\ Lamont-Doherty Earth Observatory, Palisades, New York 10964 \\ Timothy D. Herbert and John Imbrie \\ Department of Geological Sciences, Brown University, Providence, Rhode Island 02912 \\ Jean Jouzel \\ Laboratoire des Sciences du Climat et de'l Environnement, L'Orme des Merisiers, Bat 709, CEA Saclay, 91191 Gif-Sur-Ivette Cedex, France \\ Lloyd D. Keigwin \\ Woods Hole Oceanographic Institution, Woods Hole, Massachusetts 02543 \\ Karen-Luise Knudsen \\ Department of Earth Sciences, University of Aarhus, DK 8000 Aarhus C, Denmark \\ Jerry F. McManus \\ Woods Hole Oceanographic Institution, Woods Hole, Massachusetts 02543 \\ Josef Merkt \\ Niedersachsisches Landesamt für Bodenforschung, Stilleweg 2, D 30655 Hannover, Germany \\ Daniel R. Muhs \\ US Geological Survey, MS 980, Box 25046, Federal Center, Denver, Colorado 80225 \\ Helmut Müller \\ Bevenser Weg 10, App. C 004, D 30625 Hannover, Germany
}


Richard Z. Poore

US Geological Survey, National Center MS 955, 12201 Sunrise Valley Drive, Reston, Virginia 20192

Stephen C. Porter

Quaternary Research Center, University of Washington, Seattle, Washington 98195

Guy Seret

Department of Geology, Museum of Central Africa, B-3080 Tervuren, Belgium

Nicholas J. Shackleton

Department of Earth Sciences, Godwin Laboratory, University of Cambridge, Pembroke Street, Cambridge CB2 3SA, United Kingdom

Charles Turner

Department of Earth Sciences, The Open University, Milton Keynes MK76AA, United Kingdom

Polychronis C. Tzedakis

School of Geography, University of Leeds, Leeds LS2 9JT, United Kingdom

and

Isaac J. Winograd

US Geological Survey, National Center MS 432, 12201 Sunrise Valley Drive, Reston, Virginia 20192

Received September 11, 2001

The last interglacial, commonly understood as an interval with climate as warm or warmer than today, is represented by marine isotope stage (MIS) 5e, which is a proxy record of low global ice volume and high sea level. It is arbitrarily dated to begin at approximately $130,000 \mathrm{yr}$ B.P. and end at $116,000 \mathrm{yr}$ B.P. with the onset of the early glacial unit MIS 5d. The age of the stage is determined by correlation to uranium-thorium dates of raised coral reefs. The most detailed proxy record of interglacial climate is found in the Vostok ice core where the temperature reached current levels 132,000 yr ago and continued rising for another two millennia. Approximately 127,000 yr ago the Eemian mixed forests were established in Europe. They developed through a characteristic succession of tree species, probably surviving well into the early glacial stage in southern parts of Europe. After ca. 115,000 yr ago, open vegetation replaced forests in northwestern Europe and the proportion of conifers increased significantly farther south. Air temperature at Vostok dropped sharply. Pulses of cold water affected the northern North Atlantic already in late MIS 5e, but the central North Atlantic remained warm throughout most of MIS 5d. Model results show that the sea surface in the eastern tropical Pacific warmed when the ice grew and sea level dropped. The essentially interglacial conditions in southwestern Europe remained unaffected by ice buildup until late MIS $5 \mathrm{~d}$ when the forests disappeared abruptly and cold water invaded the central North Atlantic ca. 107,000 yr ago. ๑) 2002 University of Washington.

Key Words: last interglacial; Eemian; early glacial climate; MIS 5e; MIS 5d.

\section{INTRODUCTION}

At the end of the last interglacial period, over 100,000 yr ago, the Earth's environments, similar to those of today, switched into a profoundly colder glacial mode. Glaciers grew, sea level dropped, and deserts expanded. The same transition occurred many times earlier, linked to periodic shifts of the Earth's orbit around the Sun. The mechanism of this change, the most important puzzle of climatology, remains unsolved.

The problem is important, because the orbital changes today are similar to what they were at the end of the last interglacial stage (Kukla and Gavin, 1992). The long Holsteinian warm episode (marine oxygen-isotope stage 11), some 400,000 yr ago, represents an even closer analog of the current orbit. However, the relative lack of paleoclimatic evidence from that time leaves the last interglacial stage as the best available interval to study the processes and changes that led to a glaciated Earth.

To be sure, human impact on the atmosphere makes the current climate significantly different from any past one, so that the climate decline at the end of the last interglacial interval cannot be viewed as a direct analog of near-future developments. Still, the study of the last interglacial-glacial transition can teach us a great deal about how the climate system operates.

The last interglaciation is commonly labeled "Eemian." An international workshop entitled "Eemfest" was held on October 18 and 19, 1999 at the Lamont-Doherty Earth Observatory 
of Columbia University in New York. Bond, Herbert, Keigwin, Knudsen, McManus, Poore, and Shackleton reviewed the record from deep-sea sediments; Muhs and Winograd discussed coral reefs and speleothems; Bender and Jouzel reviewed ice-core records; and de Beaulieu, Cleveringa, Kukla, Merkt, Müller, Seret, Turner, and Tzedakis discussed pollen sequences. Particular attention was paid to the polar zones and to the North Atlantic realm, where the changes that took place during the declining phase of the warm period are best documented. Here we summarize the main conclusions reached by conference participants and documented in more detail in the short papers that follow.

\section{EEMIAN AND THE LAST INTERGLACIAL}

Glacials and interglacials (glaciations and interglaciations) are the principal building blocks of Quaternary stratigraphy. ${ }^{1}$ They refer to a general state of global climate. The end of an interglacial is by definition the start of a glacial. There is no unambiguous definition of an interglacial. It is commonly understood as an interval of geologic time in which the principal features of atmospheric and oceanic circulation approached those of the current world, leading to global climate as warm or warmer than during the elapsed part of the Holocene (Fairbridge, 1972). Recognizing such global climate from the geologic record is not without problems. Assignment of interglacial/glacial boundaries that would closely reflect the above concept is even more difficult.

Pleistocene interglacials were first recognized in the geologic record of formerly glaciated areas. Sediments, soils, and geomorphic features, testifying to the temporary absence of glaciers in a given region, were considered to be of interglacial age. This is how the classical Sangamon interglacial of North America was originally described. The Riss/Würm interglacial in the Alps was seen as a morphologic step separating the Low Terrace (Niederterasse) from the High Terrace (Hochterasse) of alpine rivers (Penck and Brückner, 1909). Although still used regionally, the classical Quaternary stages are increasingly being replaced by units defined in continuous deposits. Such sequences include glacier ice, deep-sea sediments, lake sediments, and loess/soil sequences.

The most universally used unit representing the last interglacial in deep-sea sediments and reflecting the total global volume of land-based ice is marine isotope stage (MIS) 5e. Its boundaries are arbitrary. In records with low climate sensitivity or less detailed subdivision, the last interglacial is commonly taken as encompassing the whole of MIS 5 or its correlatives such as, e.g., the paleosol S1 in China.

\footnotetext{
${ }^{1}$ In agreement with the overwhelming current practice of the international paleoclimatologic community and in departure from the preferred usage of Quaternary Research, we employ the terms "glacial" and "interglacial" both as adjectives and nouns. The latter refers to the time-stratigraphic interval characterized by a particular climate state and is a synonym for "interglacial period."
}

The closest representative of the last interglacial on land is the Eemian. The Eem Zone was originally described in the vicinity of the Eem River in the Netherlands by Harting (1874). The name referred to marine deposits with warm-water Lusitanian and Mediterranean mollusks (Nordmann, 1908). Zagwijn (1961) gave a more detailed overview of the type area at Amersfoort. Recently, the core at Amsterdam Terminal (AT), with a more complete sedimentary record, has been chosen as a parastratotype (Cleveringa et al., 2000; de Gans et al., 2000; van Kolfschoten and Gibbard, 2000; van Leeuwen et al., 2000). The partially varved late Saalian sediments are overlain by freshwater deposits of the early Eemian (pollen zones E1-E3). After the disappearance of permafrost in the surroundings of the Amsterdam basin, the herbs were replaced by Betula, Pinus, Ulmus, and Quercus. The freshwater sedimentary environment turned into a brackish inland sea in a very short time. This happened at the end of pollen zone E3 and the beginning of E4. After the Corylus maximum (pollen zone E4a) and expansion of Taxus (pollen zone E4b), Carpinus became important and the sea reached its highest level. At the end of the Carpinus zone the sea started to retreat and salt marshes developed. Later Alnus, Salix, and Picea became the dominant species, indicating a change to a freshwater environment. However, in the deeper parts of the basin, marine conditions continued. A mollusk from those deeper parts has a thermal ionization mass spectrometry (TIMS) date of $118,000 \pm 6300 \mathrm{yr}$ B.P. (Kruk, 1998). At that time, Abies became common in some parts of the Netherlands (Cleveringa et al., 2000).

It is now customary to interpret the Eemian as an interval of climatic amelioration associated with the spread of temperate mixed forests in areas with similar natural vegetation today. Peak eustatic sea level in Eemian time was about as high or higher than at present, and the peak climate was as warm or warmer. However, the composition of the late Eemian forests points to climate considerably more continental and colder than the current one in the same area (Zagwijn, 1961; Menke and Tynni, 1984).

When using the term Eemian, it must be kept in mind that it has been applied as a chronostratigraphic unit or a stage name but is defined using biostratigraphic units with a particular assemblage or assemblage sequence of fauna and flora whose boundaries may be diachronous (Hedberg, 1958; Salvador, 1994). The upper boundary of the Eemian, away from the region in which it was originally described, may thus cross into the last glacial period (Fig. 1).

Due to a lack of radiometric dating, the Eemian pollen zones throughout Europe were taken as coeval and dated by indirect comparison with oceanic records. However, although they do belong to the same warm episode that peaked during the last interglacial, the upper and lower boundaries may be of different ages (Cleveringa et al., 2000; Turner, 2000, 2002a). It now appears that the Eemian pollen zones in France and off Portugal may correspond to an interval considerably longer than that in the Netherlands and Germany, where the Eemian deposits were originally described (Sánchez-Goñi et al., 1999; Kukla, 2000; McManus et al., 2002; Shackleton et al., 2002). 


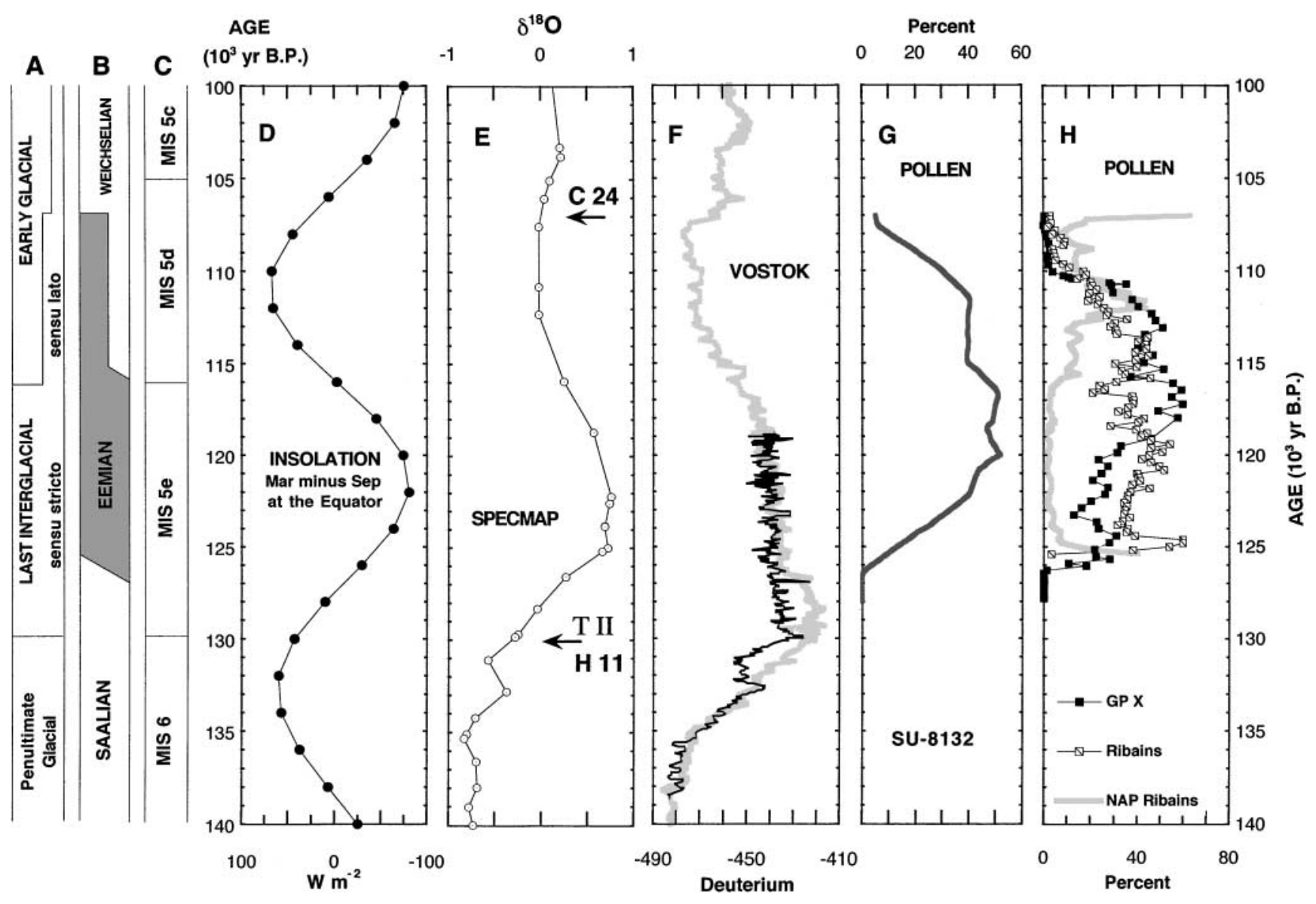

FIG. 1. Tentative correlation of stratigraphic units of the last interglacial (A and B) with marine isotope stages (C), insolation difference at equinoxes (D), and SPECMAP benthonic oxygen-isotope records, with cold-water event C24, Heinrich event H11, and Termination II (E). Vostok deuterium proxy record of air temperature (F) from Petit et al. (1999) shows the last interglacial data in gray, overlain with present interglacial values in black; Termination I (11,000 yr B.P. in black curve) is aligned with Termination II (130,000 yr B.P. in gray curve). Pollen of Carpinus plus Quercus in marine core SU 8132 off Portugal (G). Pollen records from La Grande Pile and Ribains, France, NAP is non-arboreal pollen (H). The age of the last interglacial sensu lato and sensu stricto are shown in (A). Calculations from depth to age scales were made using software from Howell (2002).

It is important to realize that the current usage of the terms "last interglacial" and "Eemian" diverges widely. We propose to restrict, as much as possible, use of the term "last interglacial" to the time when global climates were not substantially different from present. In this paper we use the term "Eemian" sensu stricto (s.s.) for sites in northwestern Europe and sensu lato (s.l.) for temperate forest episodes whose chronologic relation to northwestern Europe is unclear. However, we recommend restricting the future use of Eemian only to the equivalents of Eemian s.s. in northwestern Europe.

\section{INSOLATION AND THE LAST INTERGLACIATION}

A serious limitation in the reconstruction of events that occurred more than 100,000 yr ago is the scarcity of accurate radiometric age determinations. Still, the time-to-sediment thickness ratios, varved sequences, and other indicators of relative time, supported by uranium-thorium ages and linked to records of global ice volume and astronomic chronology, provide workable floating timetables with a reasonably high resolution. Thus, although the true age of a given paleoclimatic event of last interglacial age is known only to within a few thousand years, its relative timing with reference to an earlier or later event in the same stratigraphic system may be accurate to within centuries or even decades.

The marine isotope record is commonly tuned to astronomic chronology, represented by June insolation at the top of the atmosphere at $60^{\circ}$ or $65^{\circ}$ north latitude. This was deemed justified because the frequency of the Pleistocene gross global climate states matches the frequency of orbital variations. It has been shown that within the accuracy limits of radiometric dates, the relative global ice-volume maxima occurred when the perihelion was in boreal spring and ice minima occurred when it was in autumn (Kukla et al., 1981; Berger et al., 1981; Kukla and Gavin, 1992). The mechanism of the climate response to insolation remains unclear and the role of insolation in the high latitudes as opposed to that in the low latitudes is still debated. Model results of Clement et al. (1999) show that the growth of global ice in MIS 5d was contemporaneous with the increased frequency of warm El Niño anomalies in the eastern tropical Pacific 
(Kukla et al., 2002a). The El Niño intensity and frequency are sensitive to the difference of equinoctial insolation. The difference increases with higher eccentricity, which ultimately controls the amplitude of the precessional cycle. According to the model, the transition from a relatively cold to a relatively warm Pacific took only about $3000 \mathrm{yr}$, during which the perihelion shifted from late December to February (Kukla et al., 2002a). The difference between March and September insolation at the equator, shown in Figure 1, is a convenient index that correlates with paleoclimatic data more closely than does the summer insolation at $65^{\circ} \mathrm{N}$. It describes the difference in the strength of the Sun's beam (equinoctial seesaw) which affects any point on the Earth in the same way.

Correlation of independently timed paleoclimatic evidence shows that the interglaciations, including the current one, followed intervals of high obliquity coincident with June perihelion (Kukla et al., 1981). The warmest and least variable parts of past interglacials lasted for about 10,000-12,000 yr, during which the perihelion shifted from June to December. Glaciers grew and global climate deteriorated when the perihelion progressed from December toward February and March (Follieri et al., 1988; Kukla and Gavin, 1992).

June perihelion and the obliquity peak occurred almost simultaneously 11,000 yr ago. However, during the last interglacial, mid-June perihelion at 127,000 yr B.P. arrived later than the obliquity peak at $131,000 \mathrm{yr}$ B.P. Possibly this lag played a role in the early warming signs observed in the Southern Hemisphere. The obliquity cycle there is more strongly reflected in climate proxies than in the Northern Hemisphere. In either case, the link between global climates and orbital variations appears to be complicated and not directly controlled by June insolation at latitude $65^{\circ} \mathrm{N}$. We strongly discourage dating local climate proxies by unsubstantiated links to astronomic variations.

\section{DEEP OCEAN STRATIGRAPHY}

The cornerstone of Quaternary stratigraphy is the record of the oxygen isotope ratio of benthonic foraminifera (Shackleton, 1967; Pisias et al., 1984). It closely reflects the variation of global ice volume. In the high-resolution SPECMAP chronology of Martinson et al. (1987), the last interglacial is labeled as MIS 5e (Shackleton, 1969). It lasted from about 130,000 to $116,000 \mathrm{yr}$ B.P. The dates are approximate, due to the arbitrary nature of the boundaries and heavy dependence of the SPECMAP time scale on astronomic tuning. However, they are supported by relatively accurate radiometric determinations of emerged coral reefs and we therefore accept them as a framework for our further discussion. The boundaries of the interglacial interval are MIS 5/6 and MIS 5e/5d, drawn arbitrarily halfway between the light isotopic peak and the neighboring heavy isotopic troughs of MIS 5d and MIS 6. In addition to the isotope stages, marine stratigraphers also use numbered events, such as MIS 5.31 or MIS 5.4 (e.g., Martinson et al., 1987). These are characteristic turning points of isotopic curves which facilitate detailed core-to-core correlations. MIS stages are sometimes also labeled as OIS (oxygen isotope stages).

The relative input of the Northern and Southern Hemispheres to the global ice volume and the degree to which the record is affected by temperature changes of the deep water is unknown (Schrag et al., 1996). The latter, however, is definitely smaller than in the near surface waters. The benthonic marine isotope stratigraphy therefore primarily reflects global ice volume. It should be kept in mind that its link to local upper-ocean temperature or to various paleoenvironmental shifts on land is neither direct nor necessarily synchronous.

Marine isotope stages can also be recognized from planktonic foraminifera. Earlier isotope studies mostly involved planktonic species, which are more abundant. Such records are affected to a significant degree by variation of sea-surface temperature and salinity, which may be large and unrelated to the growth or dissipation of glaciers.

The transition from the isotopically heavy MIS 6 trough to the interglacial light peak of MIS 5e marks the penultimate deglaciation, which took about 10,000 years. It was labeled as Termination II by Broecker and van Donk (1970). Originally described using planktonic foraminifera, the term was later transferred to the benthonic system. In the original reference, "Termination" is used to describe both the whole interval of a relatively sharp transition of the isotopic proxy and also the midpoint of this shift. The latter usage has become most common. We strongly recommend using "Termination" only to define the midpoint of the shift in the benthonic isotope records. These are more closely related to ice-volume variations and are better suited for long-distance stratigraphic correlations than the planktonic ones. Termination corresponds approximately to the time of most rapid reduction of land-based ice and, consequently, to the most rapid rise of sea level. When referring to the entire interval of the glacial-interglacial shift, the term "transition" is more appropriate.

Because "Termination" refers to a proxy of global ice volume, but not to temperature or any other paleoclimatic variable, it may have a different age than the midpoints of transitions from the coolest to the warmest climate detected in other indicators elsewhere. For example, in the calcite precipitated from groundwater in Devils Hole, Nevada, the midpoint of the temperature transition is almost 10,000 years older than the oceanic Termination II recorded in benthonic foraminifera. A similar phase lag is observed in the Devils Hole record of the last deglaciation (Winograd et al., 1992, 1996) and in the ice-core proxy record of surface temperatures at Vostok, Antarctica (Petit et al., 1999). The difference shows that the change of global ice volume lagged behind the temperature rise at the abovementioned sites, not that Termination II is incorrectly dated. This may apply also to the recent study of Henderson et al. (2001), who provide a date of $135,200 \pm 3500 \mathrm{yr}$ B.P. for the MIS 5/6 boundary based on surficial, rather than abyssal, data. The difference between the planktonic and the benthonic datum 
is expectable in the tropics where sea-surface temperatures were relatively high during the periods of ice growth (Kukla et al., 2002a). An indirect age assignment of Termination II comes from interglacial coral reefs (Muhs, 2002). The highest eustatic sea level and, consequently, the lowest global ice volume have been dated to ca. 125,000 yr ago. The ice-volume maximum of MIS 6 is dated in the SPECMAP chronology to 135,000 yr B.P. The penultimate deglaciation thus took about $10,000 \mathrm{yr}$, the same as the last one, and its midpoint is at ca. 130,000 yr B.P. This arbitrary date of Termination II also defines the MIS 5/6 boundary and the beginning of the last interglacial. However, it should be taken into account that the steepest oxygen isotope shift occurred between 131,000 and 125,000 yr B.P., with the midpoint at 128,000 yr B.P. (Imbrie et al., 1984; Shackleton et al., 2002).

\section{SURFACE OCEAN STRATIGRAPHY}

Surface ocean temperature and salinity are reflected in the composition of the assemblages and oxygen-isotope content of planktonic foraminifera. Brief episodes of large-scale ice rafting provide additional correlation horizons in the North Atlantic realm.

The most prominent increases of ice-rafted detritus, accompanied by southward and eastward expansion of cold water in the North Atlantic during MIS 5e and 5d, are Heinrich event H11 and the cold-water event C24 (McManus et al., 1994; Fronval and Jansen, 1997; Chapman and Shackleton, 1999; Knudsen et al., 2002; Shackleton et al., 2002). H11 occurs close to the MIS 5/6 boundary. Event C24 precedes the end of the cold substage MIS 5d and closely postdates the ice-volume peak MIS 5.4. McManus et al. (2002) and Shackleton et al. (2002) place the age of this event at ca. 107,000 yr B.P. The interval, bracketed by the two major ice-rafting episodes $\mathrm{H} 11$ and C24, correlates closely with the couplet formed by MIS $5 \mathrm{e}$ and $5 \mathrm{~d}$, or in some places with the last interglacial sensu lato (Fig. 1). It encompasses a substantial part of the last interglacial period as recognized by the researchers of the Vostok ice core (Petit et al., 1999). It also corresponds with much of the Eemian (s.l.) at Grande Pile and Ribains, France and off Portugal (Kukla et al., 1997, 2002b; Shackleton et al., 2002).

Less-pronounced, temporary increases of ice rafting and expansion of cold water occurred in late MIS 5e and MIS 5d in the northern North Atlantic (Fronval and Jansen, 1997; Knudsen et al., 2002). Two oscillations of water ca. $2^{\circ} \mathrm{C}$ cooler than today were placed within MIS 5e by Knudsen et al. (2002). At least two additional ice-rafting events, C25 and C26 of MIS 5d age can be traced into the central part of the North Atlantic (Chapman and Shackleton, 1999). A prominent cooling noted in the deepsea record from the mid North Atlantic, with an estimated age of about 115,000 to 117,000 yr B.P. (Lototskaya and Ganssen, 1999), may be the same as reported at the MIS 5e/5d boundary by others (Knudsen et al., 2002; McManus et al., 2002). It has been suggested, although it is not universally accepted (Turner, 2000, 2002b), that this cold-water event possibly relates to the replacement of woodlands by open vegetation at sites in northwestern Europe. If so, then this episode would mark the end of the Eemian and the last interglacial in northwestern Europe (Caspers et al., 2002).

Replacement of Arctic species by a warm Lusitanian benthonic assemblage on the Denmark shelf was rapid. It is estimated to have taken less than $1000 \mathrm{yr}$. Surface waters in the North Atlantic warmed considerably, and the Lusitanian fauna penetrated as far north as southwestern Norway and the northern Baltic Sea. The boreal fauna, restricted today to the Norwegian Sea, invaded the Barents Sea during the Eemian. Bottom waters of the Danish shelf became $2^{\circ}-3^{\circ} \mathrm{C}$ warmer than today (Knudsen et al., 2002).

A regular sequence of millennial-scale oscillations, some 1000- to 3000-yr long, recognized from indicators of surface water properties of late Pleistocene and Holocene age in the North Atlantic were also detected in MIS 5 in the subtropical northwestern Atlantic, including substage MIS 5d (Oppo et al., 2001) and MIS 5e (Bond et al., 2001).

Surface waters off central and northern California were warmest in the early part of MIS 5e with values higher than in the Holocene (Poore et al., 1999). They were strongly influenced by warm central Pacific currents at that time and closely linked with changes of the terrestrial environment. Upwelling was noticeably weaker than today. A pollen record from a core in the Santa Barbara Basin off southern California indicates that the land climate in MIS 5e was similar or slightly warmer than at present (Heusser, 2000). Cooler conditions gradually replaced the relatively stable, warm Mediterranean-type climate, which continued well into early MIS 5d. The sequence of the Santa Barbara Basin resembles the record of Grande Pile in France. A significant and relatively rapid cooling of about $5^{\circ} \mathrm{C}$ at 118,000 to $119,000 \mathrm{yr}$ B.P. is registered in the pollen-bearing deep-sea core 1020, off the California coast.

Recently published alkenone sea-surface-temperature proxies from the region now dominated by the California Current show warming 10,000 to $15,000 \mathrm{yr}$ in advance of major deglaciations (Herbert et al., 2001). Today, similar warmings are observed in many El Niño years, supporting Kukla et al.'s (2002a) contention of frequent El Niño conditions at times of increasing global ice.

\section{CORAL REEFS AND SPELEOTHEMS}

Global ice volume is inversely related to mean eustatic sea level, which in the last interglacial period was as high or higher than today. Emerged coral reefs on tectonically stable coasts, preserved as marine terraces, can be dated by uranium-series isotopes via thermal ionization mass spectrometry. The method has typical analytical uncertainty (two sigma) of $<1000 \mathrm{yr}$ for corals of last-interglacial age. The data provide one of the few proxy records of interglacial ice volume that can be independently dated. An overview of available age determinations indicates that eustatic sea level was likely near or higher than its present level no later than ca. 130,000 yr ago. It continued rising and 
remained high until at least 115,000 years ago. This interval corresponds approximately to the duration of MIS 5e. As shown by Muhs (2002), eustatic sea level may have remained as high as at present until about 111,000 yr ago. This would be in apparent conflict with the reconstruction of ice volume during MIS $5 \mathrm{~d}$ based on marine benthonic isotopes. According to the latter, ice volume grew considerably during MIS $5 \mathrm{~d}$ and reached a relative peak ca. 110,000 yr ago. A possible explanation is that MIS 5d was a period of only modest ice growth, but deep water cooled more than commonly believed. Recent work suggests that the impact of temperature change on the benthonic oxygen isotope record has been underestimated (Schrag et al., 1996). The commonly held assumption that the temperature impact on the MIS $5 \mathrm{e} / 5 \mathrm{~d}$ shift was relatively minor deserves more detailed scrutiny. The geoid's response to water transfer from the oceans to land has to be considered as well.

A set of highly accurate ages of regional surface temperature through the last interglaciation was obtained from calcite precipitated from groundwater in Devils Hole, Nevada. The record is very similar to that of Vostok ice in showing that early warming culminated at the very beginning of MIS 5e (Winograd et al., 1997). Here, as well as in Antarctica, the temperature rise significantly preceded the decrease in global ice volume.

Another set of high-resolution age determinations comes from caves. Stalagmites and stalactites form only when there is a sufficient supply of underground water seeping in from the surface. That supply stops under permafrost or a glacier. Most interesting in this respect is the dating of the last interglacial hippopotamus fauna in Victoria Cave, central England. The flowstone enclosing the remains ranges in age from $135,000 \pm 8000 \mathrm{yr}$ at the bottom to $114,000 \pm 5000 \mathrm{yr}$ at the top (Gascoyne et al., 1981). These alpha spectrometry dates are less precise than TIMS determinations. Speleothems in Norway date to $140,000-135,000 \mathrm{yr}$ B.P. (Baker et al., 1993; Lauritzen, 1993, 1995; Winograd, 2002). If correct, these data would indicate that warming in high latitudes of both hemispheres may have begun quite early.

\section{POLAR ICE}

Five cores from the Arctic include Eemian ice. Two are from Devon Island, Canada, and one is from Camp Century, Greenland. These three high-latitudes cores correlate well over much of MIS 5, showing local proxy temperature throughout this zone to have been higher than in the Holocene. Based on an ice-flow dating model, the Devon Island cores probably reached MIS 6 ice and the Camp Century core reached the 120,000-yr-old level. (Dansgaard et al., 1971, 1972; Paterson et al., 1977).

Two additional Greenland cores, the GRIP and GISP summit cores, were drilled farther south. Their stratigraphic record is considered reliable back to about 110,000 yr B.P. The ice below that level seems to be affected by glacier tectonics (Alley et al., 1997) and surface melting. It may also have been deposited at substantially lower altitude than today, in a different atmospheric circulation regime (Cuffey and Marshall, 2000). In any case, the stratigraphies of the lowest part of the two neighboring cores seriously disagree, making the interglacial segments useless for long-distance correlation.

A complete sequence of last-interglacial ice is present at Vostok, Antarctica. This ice core extends back to $420,000 \mathrm{yr}$ ago, allowing comparison of the Holocene interval with four previous interglacials (Broecker and Henderson, 1998; Petit et al., 1999). It provides the most detailed and reliable local temperature proxy of the last interglacial (Fig. 1). Temperature at Vostok, reconstructed from deuterium data, increased gradually by about $12^{\circ} \mathrm{C}$ after the glacial minimum at $138,000 \mathrm{yr}$ B.P. It reached current values about $132,000 \mathrm{yr}$ ago and remained as high or higher for about the next 13,000 yr. At the very beginning of the interglacial, between about 130,000 and 127,000 yr ago, the temperature climbed as much as $3^{\circ} \mathrm{C}$ higher than today. Then it slowly cooled in a manner similar to that of the Holocene. A relatively rapid decline began ca. 115,000-117,000 yr ago, and over the next 10 millennia the temperature fell about $7^{\circ} \mathrm{C}$. It must be realized that the Vostok data do not record ice volume but rather the local temperature. Therefore, they are not directly linked to the marine benthonic isotope system. The gas bubbles in Vostok ice show that relatively high levels of carbon dioxide persisted from about 131,000 to at least 114,000 yr B.P., well beyond the onset of the cooling. During this time the $\mathrm{CO}_{2}$ concentration was higher than throughout most of the Holocene. Only in the most recent decades did the atmospheric concentration of $\mathrm{CO}_{2}$ rise sharply to values much higher than any recorded in the past.

The Vostok time scale was derived from the ice-flow model tied to the astronomic chronology at two points, 110,000 and $390,000 \mathrm{yr}$ B.P. The accuracy of the absolute dating of the temperature proxy of the last interglacial is estimated to be about $\pm 5000 \mathrm{yr}$ and is lower for the gases (Petit et al., 1999). In Fig. 1 we used the time scale derived from the ice-flow model and aligned the last interglacial and the Holocene records at Terminations I and II. However, if Termination II was placed not at 130,000 but at 128,000 yr B.P., the elapsed part of the Holocene would end closer to $115,500 \mathrm{yr}$ when perihelion occurred at the same time as today.

The global ice volume in interstadial MIS 5d increased considerably. It is not clear how much, for the oxygen isotope data in benthonic foraminifera may have been affected by a substantial cooling of the ocean bottom waters. In the mountains, glaciers in northern Europe did advance during this early glacial interval (Glaciation C of Mangerud et al., 1998).

Diatoms from Lake Baikal cores imply a substantial growth of glaciers in the surrounding mountains of southeastern Siberia during MIS 5d (Karabanov et al., 1998; Prokopenko et al., 2002). Faunal data from the Arctic ocean coasts indicate that sea ice was more open at that time than today (Arkhipov and Volkova, 1994), possibly in response to the increased intensity of spring insolation.

\section{POLLEN RECORDS IN LAKE SEDIMENTS}

In north-central Europe, the Eemian is a fully developed interglacial, defined on the basis of vegetation assemblages. Eemian 
forests became established when sea level stood some $40 \mathrm{~m}$ lower than the recent German Normal Sea Level datum. It stood $7 \mathrm{~m}$ below this benchmark during the interglacial peak. Isostatic movements prevent relating past sea-level variation in Germany and the Netherlands reliably to eustatic sea level (Caspers et al., 2002).

The numerous interglacial deposits in northwestern Germany typically occur in basins less than $100 \mathrm{~m}$ in diameter in the late Saalian dead-ice terrain. Sediments are usually calcareous at the base, diatomaceous in the middle, and sandy and peaty at the top. Annual laminations at Bispingen (Müller, 1974), Quakenbrück (Hahne et al., 1994), and Gross Todshorn (Freund and Caspers, 1997) provide an approximate timetable of the vegetational succession and duration of the Eemian forests. This was estimated, based on varve counts and palynological and sedimentological observations, to be about 10,000 to 11,000 yr (Caspers et al., 2002). Near Quakenbrück, the Eemian deposits rest on early Saalian till and are underlain by at least 2000 sandy, silty varves and another ca. 2000 sterile laminae. No obvious sign of a temperature oscillation of the last late-glacial type was recognized in this sequence, which may have been deposited during Saale 2 and 3 (Warthe). A mild climate oscillation is indicated by the varying presence of shrubs at other sites in northern Germany, found mostly on top of late Saalian sediments. The lithologic transition into a more clayey Eemian deposit at these sites is continuous, but the vegetation shift is abrupt (Hahne et al., 1994; Caspers et al., 2002). In the Netherlands, a cooling phase interrupted the warming in the late Saalian. It was similar to but less pronounced than that of the Younger Dryas (Cleveringa et al., 2000).

Timing of the onset of Eemian forests in Europe is unclear. The event is not independently dated. The pollen record in core MD 902540 off the coast of Portugal indicates that in southwestern Europe the forest developed within MIS 5e, considerably later than Termination II (Shackleton et al., 2002). The full expansion of the closed Eemian forests appears to have followed a stepwise, oscillatory increase in forest populations in late-glacial time between ca. 130,000 and 127,000 yr ago. In the Massif Central, France, these oscillations show a reexpansion of steppe taxa prior to the establishment of the pine-birch forest. Similarly, at Grande Pile in France the expansion of $\mathrm{Pi}$ nus was interrupted by the increase of Poaceae, Artemisia, and later Juniperus (Zeifen zone of Woillard, 1978). The onset of the Eemian in southwestern as well as in northwestern Europe was most probably parallel in time, although the actual species composition may have differed. The lack of an obvious late-glacial oscillation in northern Germany may be because the landscape at that time was not yet colonized by trees. This would make detection of any temporary climate deterioration from pollen data difficult.

In the best-studied European sequence of Eemian diatomaceous gyttja at La Grande Pile (Woillard, 1978; Guiot et al., 1989; Seret et al., 1992; de Beaulieu and Reille, 1992a; Pons et al., 1992; Kukla et al., 2002b), the forest episode was labeled the Lure interglacial (Seret et al., 1990). Here the closed for- est, which shows the typical Eemian vegetational succession, was probably established before $126,000 \mathrm{yr}$ B.P. It lasted for almost 20,000 years (de Beaulieu and Reille, 1992a; Kukla et al., 1997; Kukla, 2000). A close parallel between the concentration of nonarboreal pollen at this site and cold-water foraminifera Neogloboquadrina pachyderma sinistral in deep-sea core V29191 (Kukla et al., 1997), as well as the pollen record of core MD 952042 (Sánchez-Goñi et al., 1999), indicates that the Eemian Zone at La Grande Pile correlates with the main part of MIS 5e and most of MIS 5d. The boreal forest was abruptly replaced by open vegetation in the silty zone, Melisey I. The latter is apparently coeval with cold-water expansion C24 in the central North Atlantic, which is about 107,000 yr old (Kukla, 2000; McManus et al., 2002; Shackleton et al., 2002).

Pollen in the upper half of the Lure interglacial interval in the Grande Pile record shows a stepwise decline of deciduous trees and an increase of conifers. The proportion of evergreens, indicators of warm winters, increased simultaneously with conifers, approximately at the time of the MIS $5 \mathrm{e} / 5 \mathrm{~d}$ boundary. Forest composition thus indicates a shift toward cool summers but warm winters (Pons et al., 1992). At about 110,000 yr B.P., the mixed hardwood forest turned into a boreal taiga, supposedly in less than three centuries (Woillard, 1979). However, Turner (2002b) questions the accuracy of this estimate.

Ribains, in the French Massif Central, is another site where the flora developed in a fashion very similar to that at La Grande Pile. The basal third of a 9-m-thick homogenous diatomite contains a typical Eemian pollen succession (de Beaulieu and Reille, 1992b). The Ribains forest gave way to a cold meadow during Stadial I, which is considered coeval with Melisey I. At least three intervals within the Ribains interglacial between ca. 117,000 and 107,000 yr B.P. show an increased proportion of nonarboreal pollen. Together with high magnetic susceptibility, they indicate temporary expansion of open environments in the vicinity of the lake (Kukla et al., 2002b). Rapid replacement of mixed temperate forest by conifers in the upper part of the interglacial interval resembles the event at Grande Pile described by Woillard. A sharp decrease of water temperature shortly before the disappearance of deciduous trees and expansion of pine was detected from oxygen isotopes in diatoms (de Beaulieu and Reille, 1992b; Rioual et al., 2001).

As understood by palynologists, the end of an interglacial and the beginning of a glacial stage is marked by the replacement of forests by open vegetation (Menke and Tynni, 1984). This is arbitrarily taken to occur when the proportion of tree pollen drops below $50 \%$ of the total pollen count. When that happened in northwestern Europe, the sea again stood about $40 \mathrm{~m}$ below the German benchmark.

The boreal forests of the last few millennia of the Eemian point to a continental climate considerably cooler than present (Jessen and Milthers, 1928; Turner and West, 1968; Müller, 1974; Frenzel and Bludau, 1987; Caspers et al., 2002).

According to pollen and sedimentologic evidence, no severe or abrupt climatic changes occurred within the period of the 
Eemian zone in northwestern Germany. An apparent abrupt winter temperature drop in the Carpinus zone at Bispingen, deduced by Field et al. (1994) from transfer functions, is contradicted by macrofossils found elsewhere (Aaby and Tauber, 1995; Zagwijn, 1996).

The first half of the warm interval at La Grande Pile, Ribains, and in deep-sea cores shows a temperate mixed forest growing in a relatively uniform climate. The upper half has a considerably higher variability, with increases of conifers and nonarboreal taxa. Assuming near-uniform sedimentation rates, the variable part of the Eemian deposits started at about 115,000-117,000 yr ago.

A direct pollen count in two deep-sea cores off Portugal, SU 8132 (Turon, 1984) and MD 952042 (Sánchez-Goñi et al., 1999), confirms the presence of mixed forest in south-central Europe during MIS 5e and 5d. The C24 level in the cores is marked by a steep drop in the oxygen isotope ratio of planktonic foraminifera and by the presence of cold-water dynocyst Bitectatodinium tepikiense in the latter one. The successive appearance of Betula, followed by Quercus, then Carpinus, and finally Abies in SU 8132 begins in the lower part of MIS 5e and mimics the Eemian vegetation sequence at Grande Pile (Fig. 1). It appears that the immigration of trees to nearby lands occurred some time after Termination II, possibly ca. 126,000-127,000 yr ago (Shackleton et al., 2002).

The interglacial woodlands in Portugal and Greece were estimated to have lasted from about 127,000 or $126,000 \mathrm{yr}$ B.P. to about $107,000-110,000 \mathrm{yr}$ B.P. Similar to what occurred the Holocene, the establishment of a full interglacial forest does not coincide with the marine termination but occurs in the later part of the deglaciation. Between the base of MIS 5e and the start of forested environments, the concentration of arboreal pollen rose in several steps (Tzedakis et al., 2002).

After ca. 115,000-118,000 yr B.P., there is an overall trend toward more reduced forest cover, but the essentially interglacial conditions persisted in southern Europe until about 110,000 yr B.P., i.e., some $6000 \mathrm{yr}$ into the early glacial period. Thus, the gradual buildup of ice after 116,000 yr B.P. did not have a significant impact on land climates in this part of the world. The forest assemblages as far east as Greece declined rapidly only when ice volume increased substantially and ice-rafting episodes affected the central North Atlantic (Tzedakis et al., 2002). At the same time, during the early glacial stage, full-blown periglacial conditions affected northwestern Europe.

\section{CLIMATE OF THE LAST INTERGLACIAL AND INTERGLACIAL-GLACIAL TRANSITION}

The key existing gross climate indicators from the end of the penultimate glaciation through the end of the first cold substage of the early glaciation are tentatively correlated in Fig. 1. Due to limited radiometric dates, the correlation is tentative, representing only one of several possible reconstructions of climate progression during the described time. Given the available infor- mation, this is the variant that the majority of us consider most probable.

Global ice volume gradually decreased from the maximum attained some 135,000 to $138,000 \mathrm{yr}$ ago to its minimum ca. $125,000 \mathrm{yr}$ ago. Temperature at Vostok culminated several millennia prior to the global ice-volume minimum and peaked at the time of Termination II. Surface waters of the eastern tropical Pacific and groundwater along the western margin of the United States also warmed in advance of the lowest ice volume. Whether the same holds for tropical oceans elsewhere is unclear. Interglacial eustatic sea level reached a position equal to present sea level no later than 130,000 yr ago and continued rising until about 125,000 yr B.P. Climate fluctuations of the late-glacial type were observed locally, but they were not as intense and widespread as those during the Younger Dryas interval.

The isostatically depressed crust in northwestern Europe was flooded by the Eemian sea with its warm Lusitanian fauna after Termination II. The temperature on land peaked in the first part of the Eemian. The North Sea became connected with the Barents Sea through the Baltic in the first part of MIS 5e. Surface waters in the Baltic became a few degrees Celsius warmer than in the middle Holocene. The ice sheet in southern Greenland was substantially reduced in size, reached a lower surface elevation, and was probably affected by frequent summer melt (Cuffey and Marshall, 2000).

Tall mixed hardwood forests with a closed canopy covered much of Europe during MIS 5e. Last-interglacial environments and climates appear to have experienced a span of relative calm equally long, if not longer, than that of the current warm period. Between ca. 130,000 and 116,000 yr ago, the climate over much of the globe was at first warmer than, and later not very different from, that of the last 10 millennia. Episodes of increased ice rafting and cold water expansion toward the end of MIS 5e have been detected only in the northernmost North Atlantic.

The southern part of the Norwegian current, which today keeps northern Europe warm, registered increased ice rafting from about the time of the MIS 5e/5d boundary (Knudson et al., 2002). At approximately the same time, the rate of temperature decline increased substantially at Vostok, conifers began replacing broad-leaved trees in France, and open vegetation may have expanded in north-central and central Europe. Most of the swings toward drier or cooler climate, some of them rapid, appear to have affected Europe during MIS 5d, when glacier buildup was already under way. The swings were followed by temporary returns of milder climate superimposed on a longterm cooling trend.

Because of the lack of radiometric dates and an unclear link to deep-sea stratigraphy, the chronostratigraphic position of the Eemian in the Netherlands and elsewhere in northern Europe remains uncertain. Correlation with ocean records shows that the Eemian forests in southwestern Europe lasted well into MIS 5d. Strong arguments point to a much shorter duration of Eemian conditions in northwestern Europe, probably limited to substage 
MIS 5e. The dilemma is discussed in more detail by Turner (2000, 2002b). Biostratigraphic arguments support the coeval advance of Carpinus across Europe. If the varve counts in Germany are not underestimated, and if the beginning of the Bispingen pollen record is not significantly delayed, then the end of Eemian forests in northwestern Europe would be linked to major circulation shifts in the northernmost North Atlantic (Knudsen et al., 2002). The sea ice advance and ice growth on surrounding lands may also be temporally related (Mangerud et al., 1998). If so, the marked difference of vegetation between France and Germany, noted in the temperate interstades of MIS 5 (Woillard, 1978), would already have been established during MIS 5d.

In most cases, the reports presented at the Eemfest, and additional published information, indicate that the environmental shift from peak interglacial into early glacial environments in the Atlantic and western Europe advanced gradually from high to middle latitudes, with tropical and mid-latitude oceans being relatively warm at that time (van Kolfschoten and Gibbard, 2000). The orbital shift leading to the warming of the tropics and cooling of the high latitudes in autumn is strongly indicated as the primary cause of the interglacial decline. The stepwise sequence of relatively rapid cooling or drying events in MIS 5d, followed by partial recoveries lasting several centuries, is consistent with the expected effects of iceberg surges and changes of the thermohaline circulation.

\section{ACKNOWLEDGMENTS}

We are grateful to Denis-Didier Rousseau for proposing the Eemfest workshop and to the Climate Center at LDEO for providing financial support. This work is partly supported by NSF grant ATM 01-00830 and is LDEO Contribution 6261.

\section{REFERENCES}

Aaby, B., and Tauber, H. (1995). Eemian climate and pollen. Nature 376, 27-28.

Alley, R. B., Gow, A. J., Meese, D. A., Fitzpatrick, J. J., Waddington, E. D., and Bolzan, J. F. (1997). Grain-scale processes, folding, and stratigraphic disturbance in GISP2 ice core. Journal of Geophysical Research 102, 26,819-26,830.

Arkhipov, S. A., and Volkova, V. S. (1994). "Geological History, Pleistocene Landscapes and Climate in West Siberia." Transaction, Issue 823. Russian Academy of Sciences, Siberian Branch, United Institute of Geology, Geophysics and Mineralogy, Novosibirsk. [In Russian]

Baker, A., Smart, P. L., Edwards, R. L., and Richards, D. A. (1993). Annual growth banding in a cave stalagmite. Nature 364, 518-520.

Berger, A., Guiot, J., Kukla, G., and Pestiaux, P. (1981). Long-term variations of monthly insolation as related to climatic changes. Geologisches Rundschau 70, 748-758.

Bond, G., Kromer, B., Beer, J., Muscheler, R., Evans, M. N., Showers, W., Hoffmann, S., Lotti-Bond, R., Hajdas, I., and Bonani, G. (2001). Persistent solar influence on North Atlantic climate during the Holocene. Science 294, 2130-2136.

Broecker, W. S., and Henderson, G. M. (1998). The sequence of events surrounding Termination II and their implications for the cause of glacial-interglacial $\mathrm{CO}_{2}$ changes. Paleoceanography 13, 352-364.
Broecker, W. S., and van Donk, J. (1970). Insolation changes, ice volumes, and the $\mathrm{O}^{18}$ record in deep-sea cores. Reviews of Geophysics and Space Physics 8, 169-198.

Caspers, G., Freund, H., Merkt, J., and Müller, H. (2002). The Eemian interglaciation in northwestern Germany. Quaternary Research 58, 49-52.

Chapman, M. R., and Shackleton, N. J. (1999). Global ice-volume fluctuations, North Atlantic ice-rafting events, and deep-ocean circulation changes between 130 and 70 ka. Geology 27, 795-798.

Clement, A., Seager, R., and Cane, M. (1999). Orbital controls on the tropical climate. Paleoceanography 14, 441-456.

Cleveringa, P., Meijer, T., Leeuwen, R. J. W., de Wolf, H., Pouwer, R., Lissenberg, T., and Burger, A. W. (2000). The Eemian stratotype locality at Amersfoort in the central Netherlands: A re-evaluation of old and new data. Geologie en Mijnbouw 79, 197-216.

Cuffey, K. M., and Marshall, S. J. (2000). Substantial contribution to sea-level rise during the last interglacial from the Greenland ice sheet. Nature 404, 591-594.

Dansgaard, W., Johnsen, S. J., Clausen, H. B., and Langway, C. C. Jr. (1971). Climatic record revealed by the Camp Century Ice Core. In "The Late Cenozoic Glacial Ages" (K. K. Turekian, Ed.), pp. 37-56. Yale University Press, New Haven, CT.

Dansgaard, W., Johnsen, S. J., Clausen, H. B., and Langway, C. C. Jr. (1972). Speculations about next glaciation. Quaternary Research 2, 396-398.

de Beaulieu, J.-L., and Reille, M. (1992a). The last climatic cycle at La Grande Pile (Vosges, France). A new pollen profile. Quaternary Science Reviews 11, 431-438.

de Beaulieu, J.-L., and Reille, M. (1992b). Long Pleistocene pollen sequences from the Velay Plateau (Massif Central, France). Vegetation History and Archaeobotany 1, 233-242.

de Gans, W., Beets, D. J., and Centineo, M. C. (2000). Late Saalian and Eemian deposits in the Amsterdam glacial basin. Geologie en Mijnbouw 79, 147-160.

Fairbridge, R. W. (1972). Climatology of a glacial cycle. Quaternary Research 2, 283-302.

Field, M. H., Huntley, B., and Müller, H. (1994). Eemian climate fluctuations observed in European pollen record. Nature 371, 779-783.

Follieri, M., Magri, D., and Sadori, L. (1988). 250,000 year pollen record from Valle Di Castiglione (Roma). Pollen et Spores 30, 329-356.

Frenzel, B., and Bludau, W. (1987). On the duration of interglacial to glacial transition at the end of the Eemian interglacial (deep sea stage 5e): Botanical and sedimentological evidence. In "Abrupt Climatic Change-Evidence and Implications," Proceedings St. Hughes de Biviers NATO ARW, NATO ASI Series C, Vol. 216 (W. H. Berger and L. D. Labeyrie, Eds.), pp. 151-162. Reidel, Dordrecht.

Freund, H., and Caspers, G. (Eds.) (1997). Vegetation und Paläoklima der Weichsel-Kaltzeit im nördlichen Mitteleuropa-Ergebnisse paläobotanischer, faunistischer und geologischer Untersuchungen. Schriftenreihe Deutsche Geologische Gessellschaft 4, 1-249.

Fronval, T., and Jansen, E. (1997). Eemian and early Weichselian (140-60 ka) paleoceanography and paleoclimate in Nordic seas with comparisons to Holocene conditions. Paleoceanography 12, 443-462.

Gascoyne, M., Currant, A. P., and Lord, T. C. (1981). Ipswichian fauna of Victoria Cave and the marine palaeoclimatic record. Nature 294, 652-654.

Guiot, J., Pons, A., de Beaulieu, J.-L., and Reille, M. (1989). A 140,000-year continental climate reconstruction from two European pollen records. Nature 338, 309-313.

Hahne, J., Kemle, S., Merkt, J., and Meyer, K.-D. (1994). Eem-, Weichsel-u. saalezeitliche Ablagerungen der Bohrung "Quakenbrück GE 2." Geologisches Jahrbuch A 134, 9-69.

Harting, P. (1874). De bodem van het Eemdal. Verslagen en Mededelingen van de Koninklijke Academie van Wetenschappen afdeling Natuurkunde II, 8, 282-290. 
Hedberg, H. D. (1958). Stratigraphic classification and terminology. American Association of Petroleum Geologists Bulletin 42, 1881-1896.

Henderson, G. M., Slowey, N. C., and Fleisher, M. Q. (2001). U-Th dating of carbonate platform and slope sediments. Geochimica et Cosmochimica Acta 65, 2757-2770.

Herbert, T. D., Schuffert, J. D., Andreasen, D., Heusser, L., Lyle, M., Mix, A., Ravelo, A. C., Stott, L. D., and Herguera, J. C. (2001). Collapse of the California Current during glacial maxima linked to climate change on land. Science 293, 71-75.

Heusser, L. E. (2000). Rapid oscillations in western North America vegetation and climate during oxygen isotope stage 5 inferred from pollen data from Santa Barbara Basin (Hole 893A). Palaeogeography, Palaeoclimatology, and Palaeoecology 161, 407-421.

Howell, P. (2001). ARAND time series and spectral analysis package for the Macintosh, Brown University. IGBP PAGES/World Data Center for Paleoclimatology Data Contribution Series \#2001-044. NOAA/NGDC Paleoclimatology Program, Boulder, CO.

Imbrie, J., Hays, J. D., Martinson, D. G., Mclntyre, A., Mix, A. C., Morley, J. J., Pisias, N. G., Prell, W. L., and Shackleton, N. J. (1984). The orbital theory of Pleistocene climate: Support from a revised chronology of the marine delta ${ }^{18} \mathrm{O}$ record. In "Milankovitch and Climate, Part I" (A. Berger, J. Imbrie, J. Hays, G. Kukla, and B. Saltzman, Eds.), pp. 269-305. Reidel, Boston.

Jessen, K., and Milthers, V. (1928). Stratigraphical and paleontological studies of interglacial freshwater deposits in Jutland and north-west Germany. Danmarks Geologiske Undersøgelse II 48, 1-379.

Karabanov, E. B., Prokopenko, A. A., Williams, D. F., and Colman, S. M. (1998). Evidence from Lake Baikal for Siberian glaciation during oxygen-isotope substage 5d. Quaternary Research 50, 46-55.

Knudsen, K.-L., Seidenkrantz, M.-S., and Kristensen, P. (2002). Last interglacial and early glacial circulation in the northern North Atlantic Ocean. Quaternary Research 58, 22-26.

Kruk, R. W. (1998). "U-Series Radiometric Dating of Eemian Molluscs from the Amsterdam Basin. About the Last Period That Was Really Warm in Amsterdam.” Ph.D. Thesis, Faculty of Earth Sciences, Free University, Amsterdam.

Kukla, G. J. (2000). The last interglacial. Science 287, 987-988.

Kukla, G., and Gavin, J. (1992). Insolation regime of the warm to cold transitions. In "Start of a Glacial, Proceedings Mallorca NATO ARW, NATO ASI Series I, Vol. 3.” (G. Kukla and E. Went, Eds.), pp. 307-339. Springer-Verlag, New York.

Kukla, G., Berger, A., Lotti, R., and Brown, J. (1981). Orbital signature of interglacials. Nature 290, 295-300.

Kukla, G., McManus, J. F., Rousseau, D.-D., and Chuine, I. (1997). How long and how stable was the last interglacial? Quaternary Science Reviews 16, 605-612.

Kukla, G. J., Clement, A. C., Cane, M. A., Gavin, J. E., and Zebiak, S. E. (2002a). Last interglacial and early glacial ENSO. Quaternary Research 58, 27-31.

Kukla, G. J., de Beaulieu, J.-L., Svobodova, H., Andrieu, V., Thouveny, N., and Stockhausen, H. (2002b). Tentative correlation of pollen records of the last interglacial at $\mathrm{La}$ Grande Pile and Ribains with marine isotope stages. Quaternary Research 58, 32-35.

Lauritzen, S.-E. (1993). Natural environmental change in karst: The Quaternary record. Catena Supplement 25, 21-40.

Lauritzen, S.-E. (1995). High-resolution paleotemperature proxy record for the last interglaciation based on Norwegian speleothems. Quaternary Research 43, 133-146.

Lototskaya, A., and Ganssen, G. M. (1999). The structure of Termination II (penultimate deglaciation and Eemian) in the North Atlantic. Quaternary Science Reviews 18, 1641-1654.

Mangerud, J., Dokken, T., Hebbeln, D., Heggen, B., Ingólfsson, O., Landvik, J. Y., Mejdahl, V., Svendsen, J. I., and Vorren, T. O. (1998). Fluctuations of the Svalbard-Barents sea ice sheet during the last 150,000 years. Quaternary Science Reviews 17, 11-42.

Martinson, D. G., Pisias, N. G., Hays, J. D., Imbrie, J., Moore, T. C. Jr., and Shackleton, N. J. (1987). Age dating and the orbital theory of ice ages: Development of a high-resolution 0 to 300,000-year chronostratigraphy. Quaternary Research 27, 1-29.

McManus, J. F., Bond, G. C., Broecker, W. S., Johnsen, S., Labeyrie, L., and Higgins, S. (1994). High-resolution climate records from the North-Atlantic during the last interglacial. Nature 371, 326-329.

McManus, J. F., Oppo, D. W., and Cullen, J. L. (1999). A 0.5 million year millennial scale climate variability in the North Atlantic. Science 283, 971975.

McManus, J. F., Oppo, D. W., and Keigwin, L. D., Cullen, J. L., and Bond, G. C. (2002). Thermohaline circulation and prolonged interglacial warmth in the North Atlantic. Quaternary Research 58, 17-21.

Menke, B., and Tynni, R. (1984). Das Eeminterglazial und das Weichselfrühglazial von Rederstall/Dithmarschen und ihre Bedeutung für die mitteleuropäische Jungpleistozän-Gliederung. Geologisches Jahrbuch A 76, $1-120$.

Muhs, D. R. (2002). Evidence for the timing and duration of the last interglacial period from high-precision uranium-series ages of corals on tectonically stable coastlines. Quaternary Research 58, 36-40.

Müller, H. (1974). Pollenanalytische Untersuchungen und Jahresschichtenzahlung an der eem-zeitlichen Kieselgur von Bispingen/Luhe. Geologisches Jahrbuch A 21, 149-169.

Nordmann, V. (1908). "Molluskenfaunaen i Cyprinaleret og Mellem-Europas andre Eem-aflejringer. Studier over interglaciale aflejringer i Danmark, Holland og Nord-Tyskland.” Ph.D thesis, København University.

Oppo, D. W., Keigwin, L. D., McManus, J. F., and Cullen, J. L. (2001). Evidence for millennial scale variability during marine isotope stage 5 and Termination II. Paleoceanography 16, 280-292.

Paterson, W. S. B., Koerner, R. M., Fisher, D., Johnsen, S. J., Clausen, H. B., Dansgaard, W., Bucher, P., and Oeschger, H. (1977). An oxygen-isotope climatic record from the Devon Island ice cap, arctic Canada. Nature 266, 508-511.

Penck, A., and Brückner, E. (1909). Die Alpen im Eiszeitalter. Volumes 1-3, Tauchnitz, Leipzig.

Petit, J. R., Jouzel, J., Raynaud, D., Barkov, N. I., Barnola, J.-M., Basile, I., Bender, M., Chappellaz, J., Davis, M., Delaygue, G., Delmotte, M., Kotlyakov, V. M., Legrand, M., Lipenkov, V. Y., Lorius, C., Pepin, L., Ritz, C., Saltzman, E., and Stievenard, M. (1999). Climate and atmospheric history of the past 420,000 years from the Vostok ice core, Antarctica. Nature 399, 429436.

Pisias, N. G., Martinson, D. G., Moore, T. C. Jr., Shackleton, N. J., Prell, W., Hays, J., and Boden, G. (1984). High resolution stratigraphic correlation of benthic oxygen isotopic records spanning the last 300,000 years. Marine Geology 56, 119-136.

Pons, A., Guiot, J., de Beaulieu, J.-L., and Reille, M. (1992). Recent contributions to climatology of last glacial-interglacial cycle based on French pollen sequences. Quaternary Science Reviews 11, 439-448.

Poore, R., Dowsett, H., Barron, J., Heusser, L., Ravelo, C., Mix, A., and McHahon, A. (1999). "Microfossil and Stable Isotope Data from the Last Interglacial Records of Ocean Drilling Program (ODP) Sites 1018 and 1020." U.S. Geological Survey Open File Report 99-397.

Prokopenko, A. A., Karabanov, E. B., Williams, D. F., and Khursevich, G. K. (2002). The stability and the abrupt ending of the last interglaciation in southeastern Siberia. Quaternary Research 58, 56-59.

Rioual, P., Andrieu-Ponel, V., Rietti-Shati, M., Battarbee, R. W., de Beaulieu, J.-L., Cheddadi, R., Reille, M., Svobodova, H., and Shemesh, A. (2001). High resolution record of climate stability in France during the last interglacial period. Nature 413, 293-296. 
Salvador, A. (1994). "International Stratigraphic Guide. A Guide to Stratigraphic Classification, Terminology and Procedure." International Union of Geological Sciences, Trondheim, Norway and Geological Society of America, Boulder, CO.

Sánchez-Goñi, M. F., Eynaud, F., Turon, J. L., and Shackleton, N. J. (1999). High resolution palynological record off the Iberian margin: Direct land-sea correlation for the last interglacial complex. Earth and Planetary Science Letters 171, 123-137.

Schrag, D. P., Hampt, G., and Murray, D. W. (1996). Pore fluid constraints on the temperature and oxygen isotopic composition of the glacial ocean. Science 272, 1930-1932.

Shackleton, N. J. (1967). Oxygen isotope analyses and Pleistocene temperatures re-assessed. Nature 215, 15-17.

Shackleton, N. J. (1969). The last interglacial in the marine and terrestrial records. Proceedings of Royal Society London B 174, 135-154.

Shackleton, N. J., Chapman, M., Sánchez-Goñi, M. F., Pailler, D., and Lancelot, Y. (2002). The classic marine isotope substage 5e. Quaternary Research 58, 14-16.

Seret, G., Dricot, E., and Wansard, G. (1990). Evidence for early glacial maximum in French Vosges during last glacial cycle. Nature 346, 453-456.

Seret, G., Guiot, J., Wansard, G., de Beaulieu, J.-L., and Reille, M. (1992). Tentative palaeoclimatic reconstruction linking pollen and sedimentology in La Grande Pile (Vosges, France). Quaternary Science Reviews 11, 425-430.

Turner, C. (2000). The Eemian interglacial in the North European plain and adjacent areas. Geologie en Mijnbouw 79, 217-231.

Turner, C. (2002a). Formal status and vegetational development of the Eemian interglacial in northwestern and southern Europe. Quaternary Research 58, $41-44$.

Turner, C. (2002b). Problems of the duration of the Eemian interglacial in Europe north of the Alps. Quaternary Research 58, 45-48.

Turner, C., and West, R. G. (1968). The subdivision and zonation of interglacial periods. Eiszeitalter und Gegenwart 19, 93-101.

Turon, J.-L. (1984). Direct land/sea correlations in last interglacial complex. Nature 309, 673-676.
Tzedakis, P. C., Frogley, M., and Heaton, T. H. E. (2002). Duration of last interglacial conditions in northwestern Greece. Quaternary Research 58, 53-55.

van Kolfschoten, T., and Gibbard, P. L. (Eds.) (2000). Special Issue: The Eemian-Local sequences, global perspectives. Geologie en Mijnbouw 79(2/3), 129-367.

van Leeuwen, R. J. W., Beets, D. J., Bosch, J. H. A., Burger, A. W., Cleveringa, P., van Harten, D., Herngreen, G. F. W., Kruk, R. W., Langereis, C. G., Meijer, T., Pouwer, R., and de Wolf, H. (2000). Stratigraphy and integrated facies analysis of the Saalian and Eemian sediments in the Amsterdam-Terminal borehole, the Netherlands. Geologie en Mijnbouw 79, 161-196.

Winograd, I. J. (2002). Evidence from uranium-series-dated speleothems for the timing of the penultimate deglaciation of northwestern Europe. Quaternary Research 58, 60-61.

Winograd, I. J., Coplen, T. B., Landwehr, J. M., Riggs, A. C., Ludwig, K. R., Szabo, B. J., Kolesar, P. T., and Revesz, K. M. (1992). Continuous 500,000 year climate record from vein calcite in Devils Hole, Nevada. Science 258, 255-260.

Winograd, I. J., Coplen, T. B., Ludwig, K. R., Landwehr, J. M., and Riggs, A. C. (1996). High resolution $\delta^{18} \mathrm{O}$ record from Devils Hole, Nevada, for the period 80 to 19 ka. Eos, Transactions, American Geophysical Union 77(17), S169.

Winograd, I. J., Landwehr, J. M., Ludwig, K. R., Coplen, T. B., and Riggs, A. C. (1997). Duration and structure of past four interglaciations. Quaternary Research 48, 141-154.

Woillard, G. M. (1978). Grande Pile peat bog: A continuous pollen record for the last 140,000 years. Quaternary Research 9, 1-21.

Woillard, G. M. (1979). Abrupt end of last interglacial s.s. in north-east France. Nature 281, 558-562.

Zagwijn, W. H. (1961). Vegetation, climate and radiocarbon datings in Late Pleistocene of the Netherlands. Part I: Eemian and Early Weichselian. Mededelingen van de Geologische Stichting, Nieuwe Serie 14, 15-40.

Zagwijn, W. H. (1996). An analysis of Eemian climate in western and central Europe. Quaternary Science Reviews 15, 451-469. 